This item was submitted to Loughborough's Research Repository by the author.

Items in Figshare are protected by copyright, with all rights reserved, unless otherwise indicated.

\title{
An analysis of the environment and competitive dynamics of management research
}

PLEASE CITE THE PUBLISHED VERSION

http://dx.doi.org/10.1108/02621710910985441

PUBLISHER

(C) Emerald

VERSION

AM (Accepted Manuscript)

\section{PUBLISHER STATEMENT}

This work is made available according to the conditions of the Creative Commons Attribution-NonCommercialNoDerivatives 4.0 International (CC BY-NC-ND 4.0) licence. Full details of this licence are available at: https://creativecommons.org/licenses/by-nc-nd/4.0/

\section{LICENCE}

CC BY-NC-ND 4.0

\section{REPOSITORY RECORD}

Thomas, Howard, and Alexander D. Wilson. 2019. "An Analysis of the Environment and Competitive Dynamics of Management Research". figshare. https://hdl.handle.net/2134/18541. 


\title{
'An analysis of the environment and competitive dynamics of management research.'
}

Howard Thomas and Alex Wilson - Warwick Business School, University of Warwick, Coventry, CV4 7AL, U.K.

\begin{abstract}
Purpose: This paper examines some of the controversies facing business schools in their future evolution and pays particular attention to their competitive positioning as centres of management research.

Design/methodology/approach: The paper combines and builds on current literature to provide an analytic overview of the environment and competitive challenges to management research in business schools.
\end{abstract}

Findings: The paper assesses the impacts of a globalised environment and ever-changing competitive dynamics, for example in terms of the supply of high-quality faculty, on the activity of management research in business schools. It points out that research impacts must be judged not only in terms of theoretical development but also managerial and policy impact. However, managerial impact is difficult to measure and the 'voice of practice' must be carefully identified.

Originality/value: The paper identifies the current challenges for undertaking innovative research in business schools in light of their competitive environment. Three interrelated conjectures focussing particularly on managerial impact are raised which identify problems and limitations of current debates on management research in business schools.

Keywords: Management research, Management education, Management practice, Business schools.

Paper type: Viewpoint

\section{Introduction:}

Business schools are controversial organizations: The title of Khurana's recent book 'From Higher Aims to Hired Hands' (2007) highlights the unsure positioning of business schools in the modern university. They are heavily involved in both the activities of management education and management research. They are also competitive organizations deeply dependent upon student 
Accepted Version: Please cite: Thomas, Howard, and Alex Wilson. "An analysis of the environment and competitive dynamics of management research." Journal of Management development 28.8 (2009): 668-684.

fees, corporate sponsors, research funding, their own brand and, of course, position in the rankings.

Crainer and Dearlove capture the position of business schools succinctly: "The dilemma is this: On one hand, business schools present themselves as bona fide academic institutions. On the other, they try to demonstrate their ability to manage themselves as businesses because that, effectively, is what they are" (1998: 48). It is unsurprising therefore that business schools have to work with this schizophrenic agenda involving contradictory goals (Crainer and Dearlove, 1998).

Management research in business schools faces increasing internal and external criticism for the production of theoretically grounded but irrelevant research (Mintzberg, 2004; Pfeffer, 2007). This criticism is compounded by often unfavourable comparisons between the academic stature of business schools relative to other professional schools (e.g. medicine, law and engineering) (Bennis and O'Toole, 2005; Khurana, 2007) and to the university communities which they reside (Starkey and Tiratsoo, 2007).

The activity of management research must be considered both in terms of the competitive environment of business schools (Antunes and Thomas, 2007; Thomas, 2007) and the role of research in the management education process. It is particularly important to examine how research can energise and re-engage the brain and the voice of business schools in achieving a more effective strategic positioning in the context of the modern university. Ongoing debates suggest that there is a gap or imbalance between theory and practice in both management research and in management teaching. Business schools (and the various constituents of the research community), therefore, need to consider how best to escape their various ivory towers (Crainer and Dearlove, 1998)without sacrificing the academic rigour shown in other professional schools. Business schools may also need a renewed focus and engagement with the needs of practitioners.

This paper addresses two main issues: first is the problematic nature and role of management research for business schools as part of 'what business schools do?' Numerous strands of literature examining the role of business schools reveal the extensive discussion on what business schools do, 
Accepted Version: Please cite: Thomas, Howard, and Alex Wilson. "An analysis of the environment and competitive dynamics of management research." Journal of Management development 28.8 (2009): 668-684.

what is their function and what is their purpose? Is it to produce better, more skilled, professionals

(Khurana, 2007)? Or, perhaps, their purpose is aligned with gaining insight into the realms of

business and management - the academic pursuit of knowledge? These are of course stereotypes

and polar opposites. Indeed, various authors have commented on the precarious locale of business

schools at the nexus of teaching, researching and engaging with managers and organizations. We

examine the issue of management research in business schools, not as an isolated activity, but as

part of an array of controversial and competing options which challenge business schools' strategic

decision-making.

The second issue concerns the interrelated provision of management education and the apparently disjointed activities of research, teaching and practice. There has been much debate in this area, particularly in the ongoing debate surrounding theory and practice (see Reed, this issue) in management education. Various versions of this central argument have been identified; whether it is the double hurdles of rigour and relevance (Pettigrew, 1997) for management research, changing the process and product of management research (Pfeffer, 2007), evidence-based management (Pfeffer and Sutton, 2006a; Pfeffer and Sutton, 2006b; Rousseau, 2006; Pfeffer and Sutton, 2007; Rousseau and McCarthy, 2007) or 'folk' theories of management (Oaksford and Chater, 1998: Wensley, this issue).

It is clear that business schools face an imperative for reappraising their role as knowledge creators, educators and social institutions (c.f. Khurana, 2007; Starkey and Tempest, 2008) and, simultaneously, as competitive organizations (Antunes and Thomas, 2007; Thomas, 2007). This paper, therefore, examines the roles and development of management research in the future evolution of business schools. The following sections discuss the impacts of management research in terms of their contributions to theory development, the creation of multi-disciplinary project outputs, their output in terms of citations from journal contributions and their practice and policy impacts. These impacts are then evaluated in relation to the contemporary environment and 
Accepted Version: Please cite: Thomas, Howard, and Alex Wilson. "An analysis of the environment and competitive dynamics of management research." Journal of Management development 28.8 (2009): 668-684.

competitive dynamics of management education (Thomas, 2007) and conjectures about the future evolution of management research are provided.

\section{Impact of Management Research:}

The Association to Advance Collegiate Schools of Business (AACSB, 2007) report usefully characterises the types of impact from management research in business schools:

- Discipline-based scholarship (contributions to knowledge of management, expanding what we know as an academic body)

- Contributions to practice (contributions to improving the practice of managers and management of organizations)

- Learning and pedagogical research (contributions to mechanisms and resources for imparting the knowledge accumulated by management research and business schools)

The report goes on to propose where the value of business school output lies:

- Value to students

- Research and teaching effectiveness

- Value to practicing managers

- Value to society

The report also demonstrates that management research has created notable contributions to policy and practice - as shown in the table extracted from the AACSB report (2007: see appendix).

The authors of the report note further: "The rapid change in the size and stature of research in business schools has engendered passionate dialogue and debate. For example, business schools have recently been criticized for placing too much emphasis on research relative to teaching, and for producing research that is too narrow, irrelevant, and impractical" (AACSB, 2007: 10). Despite 
Accepted Version: Please cite: Thomas, Howard, and Alex Wilson. "An analysis of the environment and competitive dynamics of management research." Journal of Management development 28.8 (2009): 668-684.

underlining the 'passionate dialogue and debate' that surrounds the purpose of research and the problematic relationship between theory and practice, the AACSB “...does not take a position in the ongoing debate about relevance vs. rigour" (AACSB, 2007: 11).

It is important, however, to summarise the debates about the twin hurdles of academic rigour and practical relevance in management research and the impacts of management research.

\section{Impact of Good Theory:}

As mentioned earlier, critics in the field (Mintzberg, 2004; Khurana, 2007; Pfeffer, 2007; Starkey and Tiratsoo, 2007; Schoemaker, 2008) have been quick to argue that there is a substantial failure on the part of management research to engage effectively with practice. They would also argue that rankings such as the Financial Times or the Research Assessment Exercise (RAE) in the UK both provide the incentives and reinforce the requirements for business school faculty to publish in very high quality, theoretically grounded research journals - so called 'A-journals' to the detriment of other channels for their research outputs that would benefit the entire management community.

On the other hand, there is clear evidence that management research has contributed 'good' theories that influence the practice of management and that theory and practice are inextricably interrelated. "There is nothing so practical as a good theory" and equally "experience alone does not create knowledge" - Kurt Lewin. Business schools, as part of higher education, are therefore involved in the production of good [practical] theory to create [practicable] knowledge.

Indeed, the AASCB report that: “... several prominent researchers and executives take the view that the most valuable contributions of business schools to practice have come through the advancement of basic knowledge rather than the pursuit of immediate relevance" (AACSB, 2007: 18). The report indicates that there is transmission of theory to practice from business schools, particularly in 
Accepted Version: Please cite: Thomas, Howard, and Alex Wilson. "An analysis of the environment and competitive dynamics of management research." Journal of Management development 28.8 (2009): 668-684.

finance, but also from accounting, marketing, psychology, organizational behaviour and general theories of management (See the Appendix table sourced from the AASCB report 2007).

This transmission of basic knowledge is an extremely important factor in examining, to paraphrase Wensley (Forthcoming), the role of business schools in management research and of management research in business schools. Wensley examines the state of research in UK Business Schools to conclude that they are embroiled in the contested concerns of what is taught to whom, the nature of management research itself, its output and of the academic quality of research. The application of theory to practice, as illustrated by the AASCB, suggests that ties between research and practice do exist even if the process of transmission, translation (Wensley, this issue) and dissemination and consumption of research (Gabriel, 2002) are not fully understood.

\section{Impact of Multi-Disciplinary Project Outputs}

Clearly management is a multidisciplinary activity. Many of the important problems in management have a 'cross-cutting' multi-disciplinary nature, for example: Sustainability, corporate social responsibility, risk management and the management of health. Yet too often management research in business schools broadly reflects the disciplinary divisions embedded in the structure of our own organizations (Pfeffer and Fong, 2002) which, in turn, reinforce the incentive structures for academics and their careers. Schoemaker (2008) argues that for research to have an impact on the 'truly central problems of business' multi-disciplinary research teams are essential. The challenges and facets of business are complex; 'the soloist or dyadic' (ibid: 130) model of research is not wellequipped to produce insights into the world of managers. Accordingly, to gain the breadth and depth of management problems, management research requires large-scale and longitudinal research designs with multi-disciplinary teams (Schoemaker, 2008). In his paper he illustrates the success of numerous multi-disciplinary research projects that have altered our understanding and 
Accepted Version: Please cite: Thomas, Howard, and Alex Wilson. "An analysis of the environment and competitive dynamics of management research." Journal of Management development 28.8 (2009): 668-684.

the practice of 'business' with contributions including studies of non-disciplinary problem-solving by Herbert Simon (Crowther-Heyck, 2005), the 5-year MIT study of lean production in the automotive industry (Womack, Jones et al., 1990), the examination of resource allocation processes (Bower, 1986) and the identification of international competitiveness from the comparative advantage of nations (Porter, 1990). We would also draw attention to similarly influential research, 'The Aston Programme'(Pugh and Hickson, 1976; Pugh and Hinings, 1976; Pugh and Payne, 1977),'The Bradford Studies' insights into management decisions making (Hickson, Butler et al., 1986)and the seminal contributions on the nature of management work by both Henry Mintzberg (1973) and Rosemary Stewart (1967).

\section{Impacts in Terms of Citations from Journal Contributions and Performance Rankings:}

Citation-based bibliometrics are a widely-used measure to assess the impact of research. Indeed, the use of metrics and measures to assess research performance is a regular and necessary activity of any professional body (Adler and Harzing, 2009). Deans and research leaders of business schools use research citations to assess the research performance of their faculty and school. At the same time, the leaders and managers of business schools are assessed by their capacity to improve the overall performance of the institutions under their direction. As Starkey and Tiratsoo (2007) argue, in the era of hyper-competition, the deans of business schools are much akin to sports coaches (The Economist, 27th April 2006); deans are often hired to improve financial performance, experience high turnover, can be fired at will and are expected to bring money into their schools.

Business schools are ranked by a number of agencies and across a range of criteria (See: Policano, 2007). Specifically in the UK, the Research Assessment Exercise (RAE) uses measures of research output to help determine funding from the state. The Times Good University Guide uses student feedback on their university experience, staff/student ratios, expenditure by the institution per 
Accepted Version: Please cite: Thomas, Howard, and Alex Wilson. "An analysis of the environment and competitive dynamics of management research." Journal of Management development 28.8 (2009): 668-684.

student, research ranking and completion rates to rank universities. Such is the importance of rankings that business schools (indeed, departments and universities as a whole) are stuck in the process of managing a loop of demonstrable performance measurements. Whether this is the brand value of our MBA programmes, attracting faculty, RAE performance or income from research grants, the 'tyranny of rankings' (Khurana, 2007)is a pervasive institutional force. For the foreseeable future then, rankings are formative in the shaping of the competitive profile of business schools with research of central import within the ranking metrics.

The effects of rankings on research are two-fold: first through defining the means-ends linkages that underlie the fundamental purpose of business schools and second by privileging more conservative approaches in research. The first largely concerns the "folly of rewarding A while hoping for B" (Kerr, 1975: 769 cited in; Adler and Harzing, 2009: 74). Kerr (1975: 773) goes on to provides a pithy commentary on the realities of academia which are resonant with many arguments concerning the appropriateness of rankings:

"Society hopes that teachers will not neglect their teaching responsibilities but rewards them almost entirely for research and publications. This is most true at the large and prestigious universities. Clichés such as "good research and good teaching go together" notwithstanding, professors often find that they must choose between teaching and research oriented activities when allocating their time."

Of course, we would note that there are strong linkages between research and teaching and the mutual benefits that either has on the other. But, the increasing centrality of bibliographic rankings sees the reward of publishing (both in institutional standing and individual career prospects), leaving teaching as a secondary incumbent process - everyone should be an 'above average' teacher in this Lake Wobegon, Garrison Keillor world (1985). The controversy of citation and impact ratings appears to extend far beyond whether or not the research being produced is sufficiently rigorous and makes a contribution to academic knowledge. A growing concern involves the extent to which 
Accepted Version: Please cite: Thomas, Howard, and Alex Wilson. "An analysis of the environment and competitive dynamics of management research." Journal of Management development 28.8 (2009): 668-684.

the pursuit of knowledge has been sidelined in the interests of performance (Adler and Harzing,

2009). That is to say research citation metrics have become an ends in their own right; a political, rather than an academic pursuit (Lawrence, 2003; Adler and Harzing, 2009), with agencies such as the Thomson ISI's Web of Science 'impact factors' for journals having a considerable impact on the choice of journals in which leading academics target their work.

The resultant fixation with highly ranked 'A-journals' has not only prompted a shift in the meansends linkages for business schools it is also likely to promote a shift in the production of management knowledge. Pfeffer (2007) has observed two outcomes from the primacy given to Ajournal citations and their use as a proxy measure for performance. The first is that the success of the A-Journals is contingent on the quality and viability of the peer-review process. If this process is flawed, through a bias toward conventional theories, methodologies or topics, then important new theoretical statements will appear in outlets other than A-Journal publications. Indeed, Pfeffer has observed that "...many of the major theoretical contributions have appeared in books or lessprestigious journals" $(2007,1337)$. Secondly, authors of potentially important and new theoretical statements will experience difficulty in publishing their contributions in the high-impact 'A-Journals'. Rynes (2006) reports that the conservatism among journal editors has created barriers to publishing innovative research in A-journals. Of course, citations in and from A-journals are only one indicator of quality and impact. Citations per se are a robust measure of scholarly output (Mangematin and Baden-Fuller, 2008), but the danger lies where impact and citation scores become the central criterion for assessment of quality and reward in business schools.

\section{Policy Impacts of Management Research for Business Schools}

The AACSB report (2007) identifies three areas where the impacts of research are found: increasing disciplinary knowledge, contributions to the practice of management and pedagogical research. 
Accepted Version: Please cite: Thomas, Howard, and Alex Wilson. "An analysis of the environment and competitive dynamics of management research." Journal of Management development 28.8 (2009): 668-684.

Within each of these areas the AACSB identify the intellectual contributions from business schools.

For example, contributions to discipline-based scholarship are found in peer-reviewed journals,

research monographs and across the output from scholarly meetings and seminars. Contributions to practice are to be found in professional or trade journals and magazines, reports and books, as well as from presentations and meetings between academics and practitioners and also in the "popular" business press. Finally, pedagogical contributions are made in articles and cases, manuals and textbooks, instructional software and in the design and debates on business school curricula (ibid., 2007; table 1, p.14). This places management research in a centrally important role supporting the strategic positioning of business schools (Thomas and Li, Forthcoming) and for carving-out niches in management education (Antunes and Thomas, 2007).

The report by the AACSB provides a useful overview of where intellectual contributions from management research can be located. However, Davenport and Prusak (2003)suggest that there is limited transmission of new ideas for management or business from business schools. Even where the work of business school academics has been adopted in practice (by managers and by consultants) this has been through immediate channels (for example, Harvard Business Review) rather than through the high-impact rated scholarly (peer-reviewed) journals. So, while the output of management research may be aligned toward disciplinary knowledge, practice, pedagogy, or a combination of these, the impact on management practice generally is neither fully understood nor clear. Research by Baldridge et al. (2004)reveals a very weak correlation linking the academic quality of research with practical relevance.

\section{Discussion: The Environment and Competitive Dynamics of Management Research.}

In the following discussion we examine the implications for the production management research against five key factors that are shaping the dynamics of management education and research 
Accepted Version: Please cite: Thomas, Howard, and Alex Wilson. "An analysis of the environment and competitive dynamics of management research." Journal of Management development 28.8 (2009): 668-684.

(Thomas, 2007). These are the demographics of business schools, the role and nature of

technologies deployed, the ongoing globalisation of the management education sector, the increase in entrepreneurial activity and competition within the management education sector.

\section{Impacts and Implications of Demography:}

Business schools are organizations that require their own management and employment scenarios, including having the capacity and capabilities to conduct high-quality research. They are currently faced with a crisis in recruiting the high-calibre faculty who are able to conduct research and crucially, publish. This is compounded by two demographic phenomena. The first is the age of current faculty, with a population of 'baby-boomers' nearing retirement. The second is the supply and retention of management PhDs. The Advanced Institute of Management Research (AIM) (Ivory, Miskell et al., 2007) has observed that there will be a decrease of $10 \%$ population in the future in the 18-65 year old age bracket. This raises questions about whether there will be a sufficient number of workers to support growing sectors generally and education in particular. According to the AIM report, The Future of Business School Faculty, 2002/3 data suggests that $37 \%$ of management and economics faculty were due to retire in the next 15 years (up from $22 \%$ in 1994/5).

The growth of business schools has been unprecedented over the last fifty years and the current capacity for training new PhDs is lacking leaving a shortage of high-calibre faculty ready to fill positions in universities (Crainer and Dearlove, 1998; Hawawini, 2005). In addition to the fundamental lack of supply of PhDs, the retention of PhDs within academia is problematic. The higher education sector has, in relative terms, seen a decline in pay and conditions (Ivory, Miskell et al., 2007). Attractive opportunities await top PhDs in the private sector and this is particularly evident in the area of finance (Crainer and Dearlove, 1998; Hawawini, 2005). The fierce international competition between business schools for high-calibre faculty means that PhDs may be attracted by better paid positions abroad; for UK institutions this means competing with business schools in the USA, Canada and Asia (Ivory, Miskell et al., 2007). 
Accepted Version: Please cite: Thomas, Howard, and Alex Wilson. "An analysis of the environment and competitive dynamics of management research." Journal of Management development 28.8 (2009): 668-684.

Therefore, the future capability of business schools to produce quality research is contingent on the continued size and quality of their faculty. It is clear there are a number of factors that are affecting the training and retention of trained faculty, which left unresolved, will undermine the competitiveness of many business schools.

\section{Impacts and Implications of Technology:}

Advances in information and communication technologies (ICT) have changed the societies we inhabit (Bell, 1974; Castells, 2000) and transformed the opportunities and threats to business. The internet and its ensemble of technologies are at the forefront of many of these changes. Technology has also made great in-roads in changing management education (Hawawini, 2005; Thomas, 2007). Clearly, business schools' curricula and topics for research must reflect the consequences of competence-destroying innovations (McGee, Thomas et al., 2005), however, our concern here is to identify key areas where developments in ICT can enhance the research process.

The kinds of technologies that underlie blended learning (combinations of conventional and elearning technologies) should be employed in the activity of research. The potential for 'blended research' (a portfolio of traditional and ICT-driven data collection) would enhance the researchers' toolkit in terms of data collection and dissemination of research findings. The deployment of ICT to enable geographically dispersed research teams to form and disband responds to both the need for multi-disciplinary and international management research. Technology offers potential solutions to reduce the costly barriers of crossing geographical boundaries. Innovative approaches to research using ICT, especially the networking capabilities of the internet, could be harnessed to assist in multidisciplinary and internationally collaborative projects. Concerning the dissemination of research, ejournals have increased the portability and access to academic research for several years. Recent 
Accepted Version: Please cite: Thomas, Howard, and Alex Wilson. "An analysis of the environment and competitive dynamics of management research." Journal of Management development 28.8 (2009): 668-684.

innovations in online databases (Thomson ISI Web of Knowledge, Emerald Insight and others) and search facilities (Google Scholar) have helped push management research through more channels. Universities and business schools have also launched podcasts, webcasts and web TV to spotlight research, particularly for members of the public.

This vision for management research is heavily dependent on 'technologically aware' researchers. There is therefore a capacity-building challenge to train faculty and provide supporting infrastructure in using ICT in research.

\section{Impacts and Implications of Globalisation:}

The growth in world trade and the power of trading blocs has changed the nature of management. More 'internationally skilled' managers are required and equally, business schools must also adapt to the challenges of globalisation (Mangematin and Baden-Fuller, 2008). The first and most critical factor is the globalisation of management education. The growth of business schools worldwide (Antunes and Thomas, 2007)has meant that there are high-quality business schools in Asia and Europe as well as North America. Indeed, schools in Asia and Europe now grace the top 25 in the Financial Times Ratings (Global) (Mangematin and Baden-Fuller, 2008). Furthermore, within the global market for management education, some business schools have developed competitive niches based on their traditions in research (e.g. social sciences and philosophy in Europe) and different cultural perspectives as well as housing high-quality journals such as Organization Studies in the Organization Behaviour field, Journal of Management Studies in Management and European Journal of Operational Research in Operations Research. Accompanying the globalisation of business schools is greater evidence of more qualitative and practice orientated research and less prescriptive, hypothesis testing research (prevalent in US journals) in Europe. Indeed, in strategic management and organization studies, the 'strategy as practice' movement has grown in Europe as a counter balance to the more positive US tradition in these fields. Such counter-balancing should 
Accepted Version: Please cite: Thomas, Howard, and Alex Wilson. "An analysis of the environment and competitive dynamics of management research." Journal of Management development 28.8 (2009): 668-684.

improve the quality and impact of management research. European business schools are probably closer to management and management practice through their heavier emphasis on executive education and a strong drive for accreditation through bodies such as EQUIS and the EFMD than their US and Asian contemporaries. Additionally, the critical management tradition has helped increase quality of debate about the purpose and responsibility of business schools (Grey, 2004) reflected in the UK by cross disciplinary linkages between social studies (e.g. Bath, Lancaster and Warwick) and the humanities (e.g. Leicester) to create schools using critical management ideas and techniques (Antunes and Thomas, 2007).

\section{Impacts and Implications of Entrepreneurial Enterprises:}

For some time now entrepreneurial enterprise has been gaining increased recognition within business school thinking (Gartner and Vesper, 1994; Vesper and Gartner, 1997; Thomas, 2007). This is undoubtedly bolstered by the entrepreneurial role models such as, Richard Branson, Bill Gates, Steve Jobs and Alan Sugar (Thomas, 2007)who are highly visible in the public eye nationally and internationally. The lure of entrepreneurial activity is exemplified in the popular media by the television programme 'Dragons' Den' (aired in 13 countries) where potential entrepreneurs compete for funds from venture capitalists. Not only is entrepreneurship a global phenomenon, it is also in sharp contrast to the managerial archetypes of 'corporate civil servants', 'intrapreneures' or even 'MBAs' (Crainer and Dearlove, 1998; Mintzberg, 2004).

Some business schools in the UK have undertaken steps to link to local small business communities through enterprise hubs (e.g. Warwick) and include the study of ethnically and culturally specific enterprises that have grown as part of the diverse population of the UK. The establishment of ethnically/culturally specific research centres (e.g. Bradford, Leicester and Nottingham) responds to the need of management research to reflect contemporary society and contemporary businesses. This is just one example of how management research needs to respond to the world it is supposed 
Accepted Version: Please cite: Thomas, Howard, and Alex Wilson. "An analysis of the environment and competitive dynamics of management research." Journal of Management development 28.8 (2009): 668-684.

to reflect, avoiding the "...sense that individuals in the academy are not engaged in the same

profession they practice" (Bennis and O'Toole, 2005: 102). Two interrelated questions which must be asked of business schools conducting management research are first, whether they have the research capacity and research skills necessary to accommodate the entrepreneurial aspects of business? Secondly, does this fit alongside or replace the dominant 'corporate' mode of understanding? To answer these questions, ongoing research must account for entrepreneurial activity alongside and not as an alternative to existing models of business and management.

\section{Competition among Management Education Providers}

The domain of management research is not exclusive to business schools. The uncomfortable gaps between theory and practice have meant that research (in a general sense) is sometimes conducted by management consultancies, specialist research firms and so-called 'gurus'. Whilst the attraction of hiring bespoke research is undoubtedly great because it is customised and unique to a particular organization, Schoemaker (2008: 131) observes that "[t]oo often, armchair speculation and guru books fill a void that should be addressed through relevant scholarship." Nonetheless, the ways of operating and success of these competitors supports the argument that business schools are not fully engaged with managers and management practice. If, as Schoemaker (2008: 125)writes, "competition is intense, and yet winning requires collaboration", then collaboration and learning are required between management consultancies, specialist research firms and 'gurus' to begin to unravel the complexities of management practice and the means of engagement. This has resonance with our conjectures below with regard to both finding the voice of practice and engaging with management practice in developing management research in business schools.

\section{Conclusions/Future Directions:}


Accepted Version: Please cite: Thomas, Howard, and Alex Wilson. "An analysis of the environment and competitive dynamics of management research." Journal of Management development 28.8 (2009): 668-684.

As well as remaining competitive and well-attuned to the pluralistic demands for management education, business schools also need to address some of the shortcomings of management research particularly in the way research is funded, conducted, disseminated and a useful contribution to a cumulative body of knowledge. At the centre of this is the complex issue of the theory vs. practice balance and finding the means to bridge the gap between management theory and management practice. As the authors in this issue and in previous debates signal, possible avenues include experience-based and practice relevant research in the various areas of management studies to try to narrow the gap. Therefore, in the spirit of encouraging further debates about the theory/practice we offer three concluding conjectures.

\section{Conjecture 1: Finding the Voice of Practice.}

Our first conjecture takes a critical view on the ongoing controversies between management research (theory) and management practice. There is broad consensus that there are many instances of management research in business schools which are of limited relevance to management practice and that efforts to engage with practitioners are essential. The solutions to this controversy are extremely varied and include: Regaining management as a profession (Bennis and O'Toole, 2005; Khurana, 2007), developing a critical lens for conceptualising managerial problems (Grey, 2004), evidence-based approaches (Pfeffer and Sutton, 2006b; Rousseau, 2006; Pfeffer and Sutton, 2007; Rousseau and McCarthy, 2007), adapting means of translation between theory and practice (Wensley, Forthcoming) or the ideological transformation of the business school as an institution (Starkey and Tiratsoo, 2007; Starkey and Tempest, 2008; Starkey and Tempest, Forthcoming). Our conjecture is not with any of the 'solutions' being offered, more on the state of the debate itself. The 'voice of practice' has become lost; the debates on practice are very much internal to the academic community - where is the voice of practice? Business schools need to devise appropriate patterns of linkage and engagement in order to be able to listen to the competing demands of management practitioners. If this is completed effectively, business schools 
Accepted Version: Please cite: Thomas, Howard, and Alex Wilson. "An analysis of the environment and competitive dynamics of management research." Journal of Management development 28.8 (2009): 668-684.

will then be in an informed position to discuss the technicalities of engaging with management practice and thus produce results that become increasingly valuable to management.

We would argue that the current situation of only partial engagement with practice is sustained by institutionalised norms in management research through performance measures for individuals and institutions, the dominance of US, MBA models of management education and disciplinary cross-fire within management research. For example, the benchmarks and objectives for measuring practical relevance are largely internally generated. Quite often measures such as publication or media coverage of research output are taken to imply a level of engagement with practitioners.

Simultaneously, "practice" is too often used as a catch-all term in much the same way "the environment' was used to explain unintended consequences in early contingency theories of organization. Theory is inside business schools and practice is out there in the world of business. Taken to its logical conclusion, what practice is and where practice happens is often at the disposal of the researcher. Without finding a voice of practice, the practical impact of management research is largely an exercise in engineering and subsequently 'solving' research problems. This calls for, rather than a more sophisticated theory/practice debate, a more open and engaging debate with businesses, consultants, unions, trade associations, regional economic forums, various tiers of government and so on. Using these dialogues to find the voice of practice, management research is then better-positioned to adopt some of the more innovative solutions to engaging theory and practice already discussed.

\section{Conjecture 2: The Problematic Practice of Applying Management Research.}

The merits of practice relevance (Huxham, Forthcoming), pragmatism (Starkey and Tempest, Forthcoming), evidence-based research (Pfeffer and Sutton, 2006a; Pfeffer and Sutton, 2006b; Rousseau, 2006; Pfeffer and Sutton, 2007; Rousseau and McCarthy, 2007) and translation (Wensley, forthcoming) have been discussed and positioned as potentially viable means for engaging with the 
Accepted Version: Please cite: Thomas, Howard, and Alex Wilson. "An analysis of the environment and competitive dynamics of management research." Journal of Management development 28.8 (2009): 668-684.

theory-practice gap. Van de Ven and Johnson (2006) indicate that all these approaches

conceptualise the theory-practice gap in similar terms as problems of either:

1) Knowledge transfer (i.e. the output from management research cannot be implemented in practice).

2) Distinct varieties of knowledge (i.e. the formal-technical scientific knowledge created in management research is different from the practical knowledge of management. Theory and practice exist in different knowledge worlds)

3) Knowledge production (i.e. that the skills, institutional forces and rewards do not make the production of practical knowledge possible)

However, we would also like to propose the additional consideration of 'consumption' as critical in understanding the relationship between theory and practice. Gabriel argues: “... organizational theories, like other commodities, are not used in a passive way, in general, but creatively, opportunistically and individualistically. In this, they resemble cooking recipes and cookery books, which different users employ or experiment with in widely differing ways, for widely differing ends" (Gabriel, 2002: 134). In this sense, it is neither the nature of what is practiced by management nor our understanding of practice by management research that renders research output actionable by practitioners; rather, it is the combined factors of dissemination and consumption that achieve this.

Our rationale for focussing on dissemination and consumption is twofold: The first relates to the numerous criticisms of the MBA degree and the political construction of its role in corporate failure. Certainly, the MBA and its relevance in, and for, contemporary management is problematic (c.f. Managers not MBAs; Mintzberg, 2004). However, we argue that the attribution of blame for 
Accepted Version: Please cite: Thomas, Howard, and Alex Wilson. "An analysis of the environment and competitive dynamics of management research." Journal of Management development 28.8 (2009): 668-684.

corporate failure on business schools, particularly MBAs, is incomplete. Indeed the MBA may stand

'guilty as charged'. From our perspective, the absence of any analysis of dissemination and consumption of research (Gabriel, 2002) renders the cause-and-effect view between MBA education and corporate failure polemical. This critique questions the linear model of knowledge creation with business schools as knowledge creators and managers as consumers of knowledge. Secondly this approach can help towards building greater understanding of the consumption of theory from management research, which is inextricably linked to our first conjecture. The voice and character of 'practice' warrants closer attention, especially if progress is to be made through understanding practices of dissemination and consumption of management research.

\section{Conjecture 3: The Future of Business Schools.}

Are business schools necessarily the proponents of the kinds of ideological and operational change to management education and management research that are being discussed? An important question to pose is if business schools are in need of change, by whom and how can these changes be made? What can be surmised from various commentators who have addressed this area is the formidable tenacity of institutional pressures manifest in various and powerful stakeholders connected with business schools. Briefly, these comprise: The 'cash cow syndrome' (Reed, ?), the MBA model of executive education (Crainer and Dearlove, 1998; Mintzberg, 2004; Khurana, 2007), output-based performance metrics (Reed, forthcoming ; Wensley, forthcoming) and the theoretical and ideological centrality of free market economics (Khurana, 2007; Starkey and Tempest, 2008; Starkey, Hatchuel et al., 2009)(also Starkey and Tempest, forthcoming) all provide substantial barriers to change. What appears to be emerging is consensus that the gaps and controversies signal a need for change, yet relatively few authors have suggested a route forwards from the normative assertion that business schools should change. As Reed (this issue?) observes, the contributions of Khurana (2007) and Starkey and Tiratsoo (2007) offer two potential avenues for 
Accepted Version: Please cite: Thomas, Howard, and Alex Wilson. "An analysis of the environment and competitive dynamics of management research." Journal of Management development 28.8 (2009): 668-684.

change. Khurana's critique of managerialism and the business school as the institutional mainstay of the central ideology of 'investor capitalism' concludes with a call to return to the founding ideology of US business schools as professional schools. On the other hand, Starkey and Tiratsoo's (2007) vision for the future development of business schools is very different (Reed, forthcoming). The author's argue that the business school should be re-modelled around the principals of 'the agora', “... an ancient Greek term first used to describe a centre of political, commercial, social and philosophical activity, a place of congregation, a forum for citizens, a religious and cultural focus and a seat of justice" (Starkey and Tiratsoo, 2007: 212). The 'higher aims' advocated in Khurana (2007) represents a shift towards redefining the purpose of business schools as professional schools that capture the activity of management as a profession. In comparison, Starkey and Tiratsoo (2007) maintain that it is an ideological re-positioning of the business school that is required, one which engages and unites the multiple stakeholders involved in both management education and research. 
Accepted Version: Please cite: Thomas, Howard, and Alex Wilson. "An analysis of the environment and competitive dynamics of management research." Journal of Management development 28.8 (2009): 668-684.

\section{Appendix:}

\begin{tabular}{|c|c|c|}
\hline Topic & Authors & Sample Citation \\
\hline Sampling Problems in Auditing & W. Kinney & $\begin{array}{l}\text { A Decision-Theory Approach to the Sampling } \\
\text { Problem in Auditing, Journal of Accounting } \\
\text { Research, } 1975\end{array}$ \\
\hline $\begin{array}{l}\text { Valuing Intangible Assets } \\
\text { Financial Statements }\end{array}$ & B. Lev & $\begin{array}{l}\text { Intangibles: Management, Measurement and } \\
\text { Reporting, } 2001\end{array}$ \\
\hline $\begin{array}{l}\text { Statistical Methods for } \\
\text { Simulation }\end{array}$ & G. Fishman & $\begin{array}{l}\text { Concept and Method in Discrete Event Digital } \\
\text { Simulation, } 1973\end{array}$ \\
\hline $\begin{array}{l}\text { Information in Supply Chain } \\
\text { Management }\end{array}$ & $\begin{array}{l}\text { H. Lee, V. } \\
\text { Padmanabhan, S. Wang }\end{array}$ & $\begin{array}{l}\text { Information Distortion in Supply Chain: The } \\
\text { Bullwhip Effect, Management Science, } 1997\end{array}$ \\
\hline $\begin{array}{l}\text { Value of Information } \\
\text { Technology }\end{array}$ & $\begin{array}{l}\text { M. Hammer and } \mathrm{G} . \\
\text { Mangurian }\end{array}$ & $\begin{array}{l}\text { The Changing Values of Communications } \\
\text { Technology, Sloan Management Review, } 1987\end{array}$ \\
\hline Path-Goal Theory of Leadership & R. House & $\begin{array}{l}\text { A Path-Goal Theory of Leader Effectiveness, } \\
\text { Administrative Science Leadership Review, } 1971\end{array}$ \\
\hline Organizational Decision Making & $\begin{array}{l}\text { J. March, M. Cohen, J. } \\
\text { Olsen }\end{array}$ & $\begin{array}{l}\text { A Garbage Can Model of Organizational Choice, } \\
\text { Administrative Science Quarterly, } 1972\end{array}$ \\
\hline Measuring Service Quality & $\begin{array}{l}\text { B. Parasuraman, L. } \\
\text { Berry,V. Zeithaml }\end{array}$ & $\begin{array}{l}\text { A Conceptual Model of Service Quality and Its } \\
\text { Implications for Future Research, } \\
\text { Journal of Marketing, } 1985\end{array}$ \\
\hline Managing Technology & C. Christensen & $\begin{array}{l}\text { Exploring the Limits of the Technology S-Curve, Part } \\
1 \text { and Part 2, Production and Operations } \\
\text { Management Journal, } 1992\end{array}$ \\
\hline $\begin{array}{l}\text { Single-loop and Double-loop } \\
\text { Learning }\end{array}$ & C. Argyris, D. Schön & Organizational Learning, 1978 \\
\hline Knowledge Creation & I. Nonaka & $\begin{array}{l}\text { The Knowledge Creating Company, } \\
\text { Harvard Business Review, } 1991\end{array}$ \\
\hline Learning Organization & P. Senge & $\begin{array}{l}\text { The Fifth Discipline: The Art and Practice of the } \\
\text { Learning Organization, } 1990\end{array}$ \\
\hline Stock Option Back-dating & E. Lei & $\begin{array}{l}\text { On the Timing of CEO Stock Option Awards. } \\
\text { Management Science, } 2005\end{array}$ \\
\hline Goal Setting & G. Latham, E. Locke & $\begin{array}{l}\text { Goal Setting - A Motivational Technique that } \\
\text { Works. } \\
\text { Organizational Dynamics, } 1979\end{array}$ \\
\hline Motivation & F. Herzberg & $\begin{array}{l}\text { One More Time: How Do You Motivate Employees? } \\
\text { Harvard Business Review, } 1968\end{array}$ \\
\hline Rewards & S. Kerr & $\begin{array}{l}\text { On the Folly of Rewarding A, While Hoping for B. } \\
\text { Academy of Management Journal, } 1975\end{array}$ \\
\hline Poverty and Business & $\begin{array}{l}\text { C. Prahalad, A. } \\
\text { Hammond }\end{array}$ & $\begin{array}{l}\text { Serving the World's Poor, Profitably. Harvard } \\
\text { Business Review, } 2002\end{array}$ \\
\hline Strategy & M. Porter & Competitive Advantage, 1985 \\
\hline Transformational Leadership & B. Bass & $\begin{array}{l}\text { Two Decades of Research and Development in } \\
\text { Transformational Leadership, European Journal of } \\
\text { Work \& Organizational Psychology, } 1999\end{array}$ \\
\hline Costs of Downsizing & W. Cascio & $\begin{array}{l}\text { Downsizing: What Do We Know? What Have We } \\
\text { Learned? Academy of Management Executive, } 1993\end{array}$ \\
\hline Turnover & $\begin{array}{l}\text { T. Mitchell, B. Holtom, } \\
\text { T. Lee }\end{array}$ & $\begin{array}{l}\text { Why People Stay: Using Job Embeddedness To } \\
\text { Predict Voluntary Turnover. } \\
\text { Academy of Management Journal, } 2001\end{array}$ \\
\hline
\end{tabular}

Note: The table is intended only as a small set of examples to complement others provided in this report.

(Source: Table 5, AACSB Report: Impact of Research, 2007) 
Accepted Version: Please cite: Thomas, Howard, and Alex Wilson. "An analysis of the environment and competitive dynamics of management research." Journal of Management development 28.8 (2009): 668-684.

References:

AACSB (2007). Final Report of the AACSB International: Impact of Research: 51.

Adler, N. J. and A.-W. Harzing (2009). When Knowledge Wins: Transcending the Sense and Nonsense of Academic Rankings. Academy of Management Learning \& Education, Academy of Management. 8: 72-95.

Anon. (2006). Light on their feet. Economist. London.

Antunes, D. and H. Thomas (2007). "The Competitive (Dis)Advantages of European Business Schools." Long Range Planning 40(3): 382-404.

Baldridge, D. C., S. W. Floyd, et al. (2004). "Are managers from Mars and academicians from venus? Toward an understanding of the relationship between academic quality and practical relevance." Strategic Management Journal 25(11): 1063-1074.

Bell, D. (1974). The Coming of Post-Industrial Society. London, Heinemann.

Bennis, W. G. and J. O'Toole (2005). "How Business Schools Lost Their Way." Harvard Business Review 83(5): 96-104.

Bower, J. L. (1986). Managing the resource allocation process : a study of corporate planning and investment. Boston, Mass., Harvard Business School Press.

Castells, M. (2000). The rise of the network society. Oxford, Blackwell.

Crainer, S. and D. Dearlove (1998). Gravy training : inside the world's top business schools. Oxford, Capstone.

Crowther-Heyck, H. (2005). Herbert A. Simon : the bounds of reason in modern America. Baltimore, Md. ; London, The Johns Hopkins University Press.

Davenport, T. H. and L. Prusak (2003). What's the big idea? Boston, Mass., Harvard Business School Press; [Maidenhead : McGraw-Hill] [distributor].

Gabriel, Y. (2002). "Essai: On Paragrammatic Uses of Organizational Theory A Provocation." Organization Studies 23(1): 133-151.

Gartner, W. B. and K. H. Vesper (1994). "Experiments in entrepreneurship education: Successes and failures." Journal of Business Venturing 9(3): 179-187.

Grey, C. (2004). "Reinventing Business Schools: The Contribution of Critical Management Education." Academy of Management Learning \& Education 3(2): 178-186.

Hawawini, G. (2005). "The Future of Business Schools." Journal of Management Development 24(1): 770-83.

Hickson, D. J., J. Butler, et al. (1986). Top decisions : strategic decision making in organizations.

Oxford, Blackwell. 
Accepted Version: Please cite: Thomas, Howard, and Alex Wilson. "An analysis of the environment and competitive dynamics of management research." Journal of Management development 28.8 (2009): 668-684.

Huxham, C. (Forthcoming). "Forces For and Forces Against: Vagaries of - and Capacity Building forPractice Relevant Research." Journal of Management Development.

Ivory, C., P. Miskell, et al. (2007). The Future of Business School Faculty, Advanced Institute of Management Research.

Keillor, G. (1985). Lake Wobegon days, Viking.

Kerr, S. (1975). "Folly of Rewarding A, While Hoping for B." Academy of Management Journal 18(4): 769-783.

Khurana, R. (2007). From higher aims to hired hands: the social transformation of American business schools and the unfulfilled promise of management as a profession. Princeton, Princeton University Press.

Lawrence, P. A. (2003). "The politics of publication - Authors, reviewers and editors must act to protect the quality of research." Nature 422(6929): 259-261.

Mangematin, V. and C. Baden-Fuller (2008). "Global Contests in the Production of Business Knowledge: Regional Centres and Individual Business Schools." Long Range Planning 41(1): 117-139.

McGee, J., H. Thomas, et al. (2005). Strategy: Analysis and Practice. Maidenhead, McGraw-Hill.

Mintzberg, H. (1973). The nature of managerial work, New York: London, Harper and Row.

Mintzberg, H. (2004). Managers Not MBAs. London, Pearson Education.

Oaksford, M. and N. Chater (1998). Rationality in an uncertain world : essays on the cognitive science of human reasoning. Hove, Psychology Press.

Pettigrew, A. M. (1997). The Double Hurdles for Management Research. Advancement in organizational behaviour : essays in honour of Derek S. Pugh. T. Clark. London, Dartmouth Press.

Pfeffer, J. (2007). "A Modest Proposal: How We Might Change the Process and Product of Managerial Research." Academy of Management Journal 50(6): 1334-1345.

Pfeffer, J. and C. T. Fong (2002). "The End of Business Schools? Less Success than Meets the Eye." Academy of Management Learning and Education 1: 78-95.

Pfeffer, J. and R. I. Sutton (2006a). Evidence-Based Management. Harvard Business Review, Harvard Business School Publication Corp. 84: 62-74.

Pfeffer, J. and R. I. Sutton (2006b). Hard facts, dangerous half-truths, and total nonsense : profiting from evidence-based management. Boston, Massachusetts, Harvard Business School Press.

Pfeffer, J. and R. I. Sutton (2007). "Suppose We Took Evidence-Based Management Seriously: Implications for Reading and Writing Management." Academy of Management Learning \& Education 6(1): 153-155.

Policano, A. (2007). "The Rankings Game: and the Winner is..." Journal of Management Development 26(1): 43-49. 
Accepted Version: Please cite: Thomas, Howard, and Alex Wilson. "An analysis of the environment and competitive dynamics of management research." Journal of Management development 28.8 (2009): 668-684.

Porter, M. E. (1990). The Competitive Advantage of Nations, Macmillan.

Pugh, D. S. and D. J. Hickson (1976). Organizational structure in its context : the Aston programme 1. Farnborough, Hants., Saxon House [etc.].

Pugh, D. S. and C. R. Hinings (1976). Organizational structure extensions and replications: the Aston programme II. Farnborough, Hants., Saxon House.

Pugh, D. S. and R. L. Payne (1977). Organizational behaviour in its context : the Aston programme III. Farnborough, Hants., Saxon House.

Rousseau, D. M. (2006). "2005 presidential address - Is there such a thing as "evidence-based management"?" Academy of Management Review 31(2): 256-269.

Rousseau, D. M. and S. McCarthy (2007). Educating Managers From an Evidence-Based Perspective. Academy of Management Learning \& Education, Academy of Management. 6: 84-101.

Rynes, S. L. (2006). "'Getting on board" with AMJ: Balancing quality and innovation in the review process." Academy of Management Journal 49(6): 1097-1102.

Schoemaker, P. J. H. (2008). "The Future Challenges of Business: Rethinking Management Education." California Management Review 50(3): 119-139.

Starkey, K., A. Hatchuel, et al. (2009). "Management Research and the New Logics of Discovery and Engagement." Journal Of Management Studies 46(3): 547-558.

Starkey, K. and S. Tempest (2008). "A Clear Sense of Purpose? The Evolving Role of the Business School." Journal of Management Development 27(4): 379-390.

Starkey, K. and S. Tempest (Forthcoming). "From Crisis to Purpose." Journal of Management Development.

Starkey, K. and N. Tiratsoo (2007). The business school and the bottom line. Cambridge, Cambridge University Press.

Stewart, R. (1967). Managers and their jobs: a study of the similarities and differences in the ways managers spend their time, London: Macmillan.

Thomas, H. (2007). "An Analysis of the Environment and Competitive Dynamics of Management Education." Journal of Management Development 26(1): 9-21.

Van de Ven, A. and P. Johnson (2006). "Knowledge for Theory and Practice." Academy of Management Review 31(4): 802-821.

Vesper, K. H. and W. B. Gartner (1997). "Measuring progress in entrepreneurship education." Journal of Business Venturing 12(5): 403-421.

Wensley, R. (Forthcoming). "Research in UK Business Schools or Management Research in the UK?" Journal of Management Development. 
Accepted Version: Please cite: Thomas, Howard, and Alex Wilson. "An analysis of the environment and competitive dynamics of management research." Journal of Management development 28.8 (2009): 668-684.

Womack, J. P., D. T. Jones, et al. (1990). The Machine that changed the world : based on the Massachusetts Institute of Technology 5-million dollar 5-year study on the future of the automobile. New York, Rawson Associates : Collier Macmillan Canada : Maxwell Macmillan Interanational. 